Abstracta Iranica Abstracta Iranica

Revue bibliographique pour le domaine irano-aryen

Volume 26 | 2005

Comptes rendus des publications de 2003

\title{
« Beyt-hā-ye zan-setizān-e dar Šāh-nāme ». Našr-e Dāneš, 20, 2 (1382/2003), pp. 19-26.
}

\section{Charles-Henri de Fouchécour}

\section{Q OpenEdition \\ 12 Journals}

Édition électronique

URL : http://journals.openedition.org/abstractairanica/1898

ISSN : 1961-960X

\section{Éditeur :}

CNRS (UMR 7528 Mondes iraniens et indiens), Éditions de l'IFRI

\section{Édition imprimée}

Date de publication : 15 mai 2005

ISSN : 0240-8910

\section{Référence électronique}

Charles-Henri de Fouchécour, « «Beyt-hā-ye zan-setizān-e dar Šāh-nāme ». Našr-e Dāneš, 20, 2

(1382/2003), pp. 19-26. », Abstracta Iranica [En ligne], Volume 26 | 2005, document 356, mis en ligne le 07 décembre 2005, consulté le 25 septembre 2020. URL : http://journals.openedition.org/

abstractairanica/1898

Ce document a été généré automatiquement le 25 septembre 2020.

Tous droits réservés 


\title{
« Beyt-hā-ye zan-setizān-e dar Šāh- nāme ». Našr-e Dāneš, 20, 2 (1382/2003), pp. 19-26.
}

\author{
Charles-Henri de Fouchécour
}

1 Un dossier à ajouter aux enquêtes sur la femme dans le Livre des Rois de Ferdowsī. Le sujet est nouveau, il s'agit des femmes querelleuses ou rebelles, au sens péjoratif. En huit occurrences, désobligeantes pour une femme, l'A. montre, par comparaison des manuscrits, qu'il s'agit de beyts ajoutés tardivement par des copistes. Mais il existe dix autres cas, où les beyts sont bien désobligeants à l'égard des femmes. Les ayant cités, l'A. s'attache à montrer qu'il existe d'autres beyts tout à l'honneur des femmes et qu'on ne peut juger des premiers qu'en les rapportant aux personnages du texte qui parlent.

\section{INDEX}

Thèmes : 11.1.1. Littérature persane classique

Keywords : Shāhnāmeh, Šāh-nāme

nompropre Ferdowsī

\section{AUTEURS}

\section{CHARLES-HENRI DE FOUCHÉCOUR}

Fondateur de la revue Abstracta Iranica - Paris 